\title{
一般住民の骨粗鬆症に関する疫学調査
}

$\begin{array}{ccccc}\text { 鹿児島赤十字病院リウマチセンター } & & \\ \text { 中 村 宏 } & \text { 志・大 } & \text { 西 } & \text { 敏 } & \text { 行 } \\ \text { 児 島 一 } & \text { 久・泉 } & \text { 原 } & \text { 智 } & \text { 麿 } \\ \text { 松 } & \text { 田剛 } & \text { 正・新 村 } & & \text { 健 }\end{array}$

鹿児島大学整形外科

武富 栄 二・酒 匂崇

\section{Epidemologic Study on Osteoporosis in General Populations}

by

Hiroshi Nakamura, Toshiyuki Ohnishi, Kazuhisa Kojima, Tomomaro Izumihara, Takemasa Matsuda and Itaru Niimura

The Center for Rheumatic Diseases, Kagoshima Red Cross Hospital

Eiji Taketomi and Takashi Sakou

Department of Orthopaedic Surgery, Faculty of Medicine, Kagoshima University, Kagoshima

We conducted an epidemologic study on osteoporosis in Oura, Kagoshima prefecture. 530 Subjects (214 male and 316 female) ranging in age from 40s to 70 s were incuded. The diagnostic criteria of osteoporosis proposed by the MHW (Ministry of Health and Welfare) was used, with those having more than four points diagnosed as osteoporosis. In the $60-69$ year age group $4 \%$ of male and $26 \%$ of female subjects were diagnosed as having osteoporosis ; in the $70-79$ year group $18 \%$ of male and $57 \%$ of female wer osteoporosis. The number of offected females was signficantly higher than that of males. From examining females aged greater than 50 years for causative factors, it was found that thin women, and women from 40 to 43 years old in the early menopause period had a higher incidence of osteoporosis. However no significant difference in life style and diet was found among those examined.

はじめに

高齢化社会の到来に伴い, 種々の合併症に対する関 心が高まってきており，骨粗鬆症に関しても予防およ び治療に対して様々の分野からアプローチがなされて きている，しかし，その成因についてはいくつかの要 因が重なって発症するため，不明な点が多い，その成 因の究明にとって, 疫学調査は重要な手段のひとつで あるが報告は少ない。今回，われわれはレントゲン検 診車を用いて骨粗鬆症の疫学調査を行ったので報告す る.

\section{対象および方法}

文象とした地域は，鹿児島県の南西部に位置し農業 を基盤とする大浦町で，全人口は 3,578 人である。年 代別人口構成をみると, 60 -70 代の人口が多くを占め る典型的な高齢化社会の町である. 今回の検診数は, 40 代 68 人 $19 \%, 50$ 代 103 人 $26 \% ， 60$ 代 205 人 28 $\%, 70$ 代 174 人 $30 \%$ で, 計 550 人であり, うちアンケ 一ト内容が不完全なまた RA 等の除外疾患を除く 530 人で, 男性 214 人, 女性 316 人を対象とした。この年 代の約 $27 \%$ にあたる。 
方法は，厚生省退行期骨粗鬆症診断基準額ほほ確実 例の 4 点以上を骨粗粉症とし，1）年代別骨粗鬆症発 症率，2）年代別脊椎圧迫骨折の頻度，3）骨折の既 往部とその頻度，4）年齢, 性を除く骨粗鬆症の危険 因子と考えられている, 日常生活の活動性, 食事内容, 体型, 授乳期間, 閉経年齢について検討を行った。

\section{結果}

年代別骨粗鬆症発症率をみると, 60 代で男性 $4 \%$, 女性 $26 \%, 70$ 代で男性 $18 \%$, 女性 $57 \%$ と年齢ととも に増加し,かつ女性に有意に多くみられるようになり,

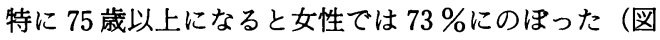
- 1 ).

年代別脊椎圧迫骨折の頻度をみると 60 代で男性 5 \%, 女性 $14 \%$, 70 代で男性 $17 \%$, 女性 $31 \%$ と女性に 有意に多くみられ, 70 代以上では多椎体にわたる例が 多かった。

骨折の既往部位とその頻度をみると, 大腿骨頝部骨 折 1 例, 橈骨遠位端骨折 15 例, 上腕骨近位端骨折 4 例, 肋骨骨折 5 例, 明らかな外傷による脊椎圧迫骨折 2 例, その他 9 例，計 36 例 $7 \%$ に見られた.

以上の結果より，骨粗鬆症の危険因子は，高齢の女 性がその一因であることは, 従来の報告通りである. 今回は 50 歳以上の女性で骨粗鬆症の危険因子につい て検討を行った。

日常生活の活動性の評価を乗松等の報告に従って分 類した"1).この分類に従って, ADL 指数と骨粗鬆症発 症率についてみると, stage II $36 \%$, stage III $32 \%$, stage IV $39 \%$, stage V $3 \%$, stage Vの群で有意に

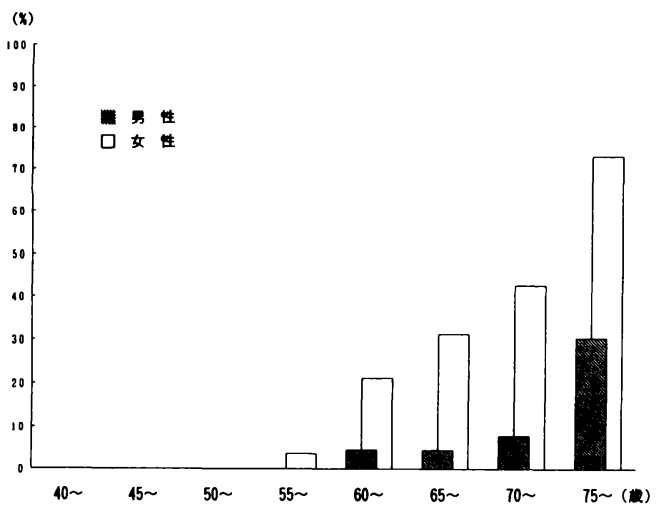

図 1 年代別骨粗鬆症発症率
低かったが, 平均年齢が 55 歳と若く, 他の群との比較 はできなかった。

食事と骨粗箖症発症率について検討した。アンケー 卜調査では, 牛乳, 小魚, 海草類等について, 毎日捸 取，2-3日おき，攝取しないの 3 項目に分けて調査 した. 牛乳についてみると毎日摄取群では $39 \%$, 非摄 取群では $33 \%$ と有意差はみられなかった.ただし飲ん でいた期間についてはアンケートを取っていない.ま た. 食物についても有意差はなかった。

体型と骨粗钐症発症率についてみたが，体型は身長 と体重より算出した BMI（body massindex）を用い た. 標準群で $32 \%$, 肥満群で $31 \%$, やせ群で $40 \%$ と 有意差はみられなかったが, やせ群で骨粗鬆症発症率 が高い傾向がみられた（図一2）。

授乳期間と骨粗鬆症発症率についてみると，0 から 1 年群で高い值を示したが， 1 年以降は授乳期間が延 びるにつれてその発症率は漸増する傾向にあった（図 $-3)$.

閉経年齢と骨粗箖症発症率について検討した. 40-43 歳の早発閉経群と 47-51 歳の正常閉経群に分け, 少な くとも閉経後 10 年経過した 60 歳以上を対象としてみ たが早期閉経群 $41 \%$, 正常狂経群 $29 \%$ と早発閉経群 で発症率が高い傾向がみられたが，有意差はみられな かった（図一 4$)$.

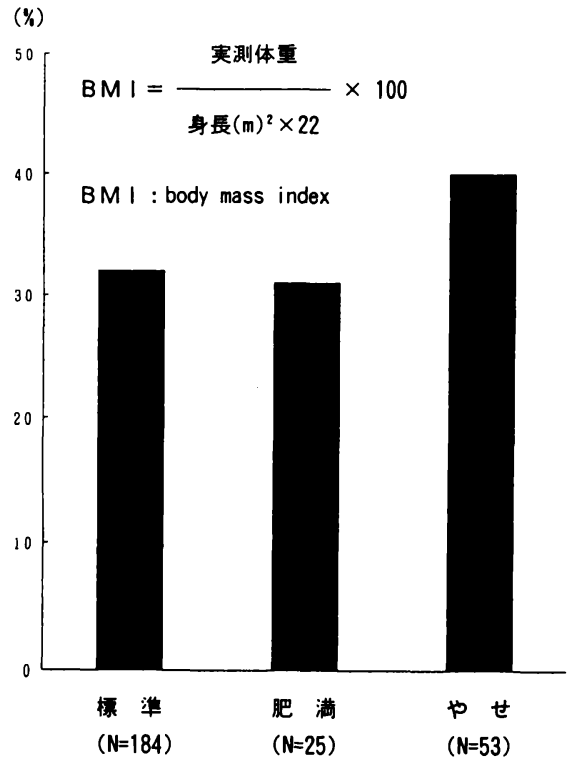

図 2 体型と骨粗鬆症発症率（50 歳以上女性） 


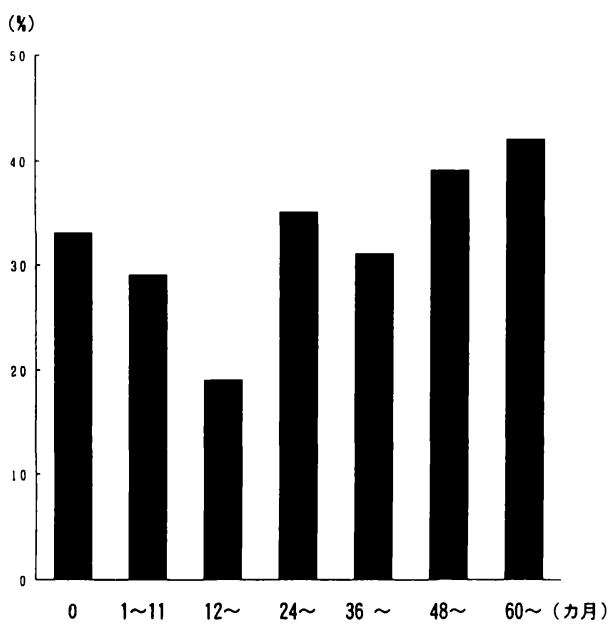

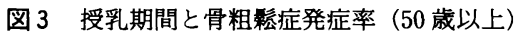

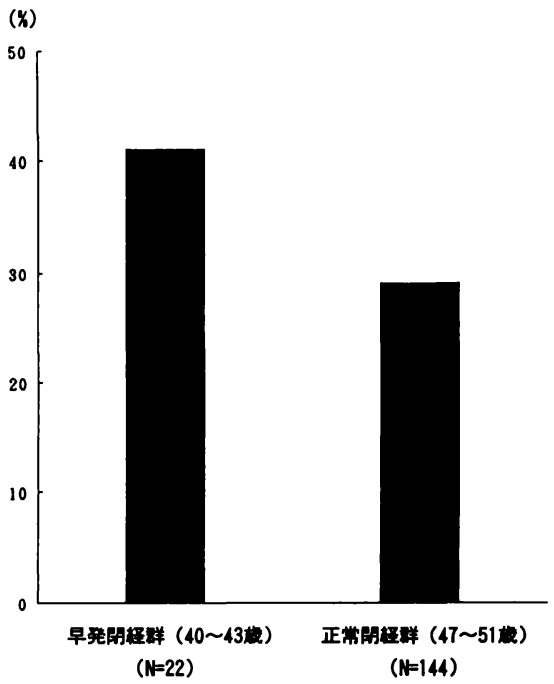

図 4 閉鎖年齢と骨粗叞症発症率（60 歳以上）

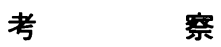

今回, 厚生省シルバーサイエンス研究班の退行期骨 粗鬆症診断基準にのっとり, 骨粗鬆症の疫学調查を行 つたが，本症の発症率については今までの報告とほほ 同様な結果が得られ2)3), 重要な因子は年齢, 性であっ
た。

その他の危険因子については，一般に言われている 日常生活の活動性, 食事内容では, 明らかな傾向は見 いだせ得なかった。この町では, 高齢であっても農作 業に従事している人が多く, 都市部でみられるような 日常生活の活動性の違いによる発症率の差がみられな かったと思われる. 食事内容についても, 思った以上 に牛乳や小魚を摂取しており，住民の本症への関心の 高さがうかがえた。しかし，本症の発症率に有意差が みられなかったのは, 加令による腸管の Ca 吸収の低 下によるものか, 一日 Ca 必要摂取量に達しているの か,さらには他の栄養素の捸取状況等4)細かな内容の 検討が必要と思われた。体型については, 従来の報告 通りやせ型の人に発症しやすい傾向がうかがえた。授 乳期間については, 本症の発症には関係しないという 報告もみられるが5)，今回の調査では授乳期間が長く なる群で年齢がやや高くなるものの, 発症しやすい傾 向がみられた. 閉経については, 早期閉経群で発症率 が高い傾向をみられ, エストロゲンがその発症に重要 な因子であることが示唆された。

$$
\text { ま と め }
$$

1.レントゲン検診車を用いて 40-70 代の住民を対 象に骨粗鬆症検診を行った。

2. 骨粗鬆症の危険因子は，年歯，性別に有意であ つたが，体型，授乳期間，閉経年令も誘因のひとつに あげられた。

\section{参 考 文 献}

1）乗松尋道, 他：オステオポローシスの疫学一沖縄県 の場合一。本骨代謝誌, $8: 174-183,1990$.

2) 井上哲郎：骨粗鬆症の臨床像. The Bone, $4: 39$ 47, 1990 。

3）藤原佐枝子, 他：一老年疾病の疫学一骨粗影症. Gerat. Red, 28 : 945-949, 1990.

4）七田恵子：加齢に伴う骨塩量減少に影響する因子一 カルシウム摄取及び身体活動の影響一. 日老医誌, 24 ： 544-553, 1987.

5）大頭敏文：骨粗鬆症の疫学, 臨婦産, $44: 148-152$, 1990. 